\title{
The purification, characterization and role of the $d$-type cytochrome oxidase of Klebsiella pneumoniae during nitrogen fixation
}

\author{
ANDREW SMITH, ${ }^{1}$ SUSAN HILL ${ }^{2}$ and Christopher ANTHONY ${ }^{1 *}$ \\ ${ }^{1}$ Biochemistry Department, University of Southampton, Southampton SO9 3TU, UK \\ ${ }^{2}$ AFRC-IPSR, Nitrogen Fixation Laboratory, University of Sussex, Brighton BN1 9RQ, UK
}

(Received 19 June 1989; revised 6 September 1989; accepted 28 September 1989)

\begin{abstract}
Klebsiella pneumoniae synthesized only $b$-type and $d$-type cytochromes under the wide range of growth conditions tested, and reaction with $\mathrm{CO}$ revealed two potential oxidases. The $o$-type oxidase was produced only in the presence of $\mathrm{O}_{2}$ and appeared to be repressed by glucose. The $d$-type oxidase was, by contrast, produced only in the absence of measurable $\mathrm{O}_{2}(<1 \mu \mathrm{M})$, and was the only oxidase expressed in nitrogen-fixing conditions. It was extracted from the membrane, purified and shown to be similar to that from $E$. coli in being a heterodimer (subunits of $M_{\mathrm{r}} 52000$ and 35000), in containing two distinguishable $b$ haems and haem $d$ (one or two molecules per molecule of oxidase), and in being able to react with $\mathrm{O}_{2}$ to give a stable oxygenated intermediate. The purified $d$-type cytochrome oxidase had a very high affinity for $\mathrm{O}_{2}\left(K_{\mathrm{m}} 20 \mathrm{nM}\right.$; measured by the spectral properties of leghaemoglobin). It is proposed that this provides a role for this oxidase in lowering the $\mathrm{O}_{2}$ concentration to allow nitrogenase synthesis and function, and to provide a terminal oxidase to permit electron-transport-coupled ATP synthesis which supports the increase in efficiency of nitrogen fixation observed under microaerobic conditions.
\end{abstract}

\section{Introduction}

Nitrogen fixation in the facultative anaerobe Klebsiella pneumoniae occurs only in anaerobic or microaerobic conditions. Low $\mathrm{O}_{2}$ concentrations (optimum about $30 \mathrm{~nm}$ ) enhance nitrogenase synthesis, activity and efficiency (mols $\mathrm{N}_{2}$ fixed per mol of carbon substrate consumed) compared with that occurring during anaerobiosis (Hill, 1976, 1988; Hill et al., 1984). This is presumably due to provision of ATP for nitrogenase activity by way of $\mathrm{O}_{2}$-dependent respiration. Higher $\mathrm{O}_{2}$ concentrations inhibit both synthesis and activity of nitrogenase, with $50 \%$ inhibition occurring at about $100 \mathrm{nM}-\mathrm{O}_{2}$ which is close to the estimated $K_{\mathrm{s}}$ of the dominant terminal oxidase (about $80 \mathrm{nM}$, estimated from $\mathrm{O}_{2}$-consumption measurements with whole bacteria) (Bergersen \& Turner, 1979; Bergersen et al., 1982; Hill et al., 1984). This raises the important question of the nature of the oxidase(s) responsible for respiration at the very low $\mathrm{O}_{2}$ (microaerobic) concentrations that support more efficient nitrogen fixation, and which is involved in creating these conditions suitable for derepression of nitrogenase synthesis.

Abbreviation: TMPD, 2,3,5,6-tetramethyl p-phenylenediamine dihydrochloride.
Very little information is available on the cytochromes of $K$. pneumoniae and none at all is available for nitrogenfixing conditions (Harrison, 1972) but, because $K$. pneumoniae is related to $E$. coli, it might be expected that their cytochrome complements would be similar. E. coli has two terminal oxidases, an $o$-type oxidase and a $d$ type oxidase (Anraku \& Gennis, 1987; Ingledew \& Poole, 1984). They are similar in oxidizing ubiquinol but they differ in their $\mathrm{O}_{2}$-affinity and regulation of their synthesis. The cytochrome $o$ complex has a lower affinity for $\mathrm{O}_{2}\left(K_{\mathrm{m}}=2.9 \mu \mathrm{M}\right)$ and is predominant during growth at high $\mathrm{O}_{2}$ concentrations, whereas cytochrome $d$ has a higher affinity for $\mathrm{O}_{2}\left(K_{\mathrm{m}}=0.38 \mu \mathrm{M}\right)$ and is predominant at lower $\mathrm{O}_{2}$ concentrations (Kita et al., 1984a, $b$; Rice \& Hempfling, 1978). Observations using antibodies to cytochrome $d$ of $E$. coli suggested that the membranes of $K$. pneumoniae are similar to those of $E$. coli in containing a $d$-type oxidase (Kranz et al., 1984; Kranz \& Gennis, 1985).

The present paper shows that the sole oxidase detectable during microaerobic nitrogen fixation is a $d$ type oxidase. This has been purified and characterized, and its exceptionally high affinity for $\mathrm{O}_{2}$ (measured with leghaemoglobin) shown to be compatible with a critical role in supporting microaerobic nitrogen fixation. 


\section{Methods}

Growth of bacteria in continuous culture and preparation of membranes for determination of cytochrome and oxidase content. $\mathrm{K}$. pneumoniae (oxytoca) (NCIB 12204) was maintained as described for E. coli by Smith et al. (1988). The growth medium contained $\mathrm{Na}_{2} \mathrm{HPO}_{4}(73 \mathrm{~mm})$, $\mathrm{KH}_{2} \mathrm{PO}_{4}(18 \mathrm{mM})$, nitriloacetic acid $(300 \mu \mathrm{M})$ and the following (final concentration in $\mathrm{mg} \mathrm{l}^{-1}$ ): $\mathrm{MgSO}_{4} .7 \mathrm{H}_{2} \mathrm{O}(60) ; \mathrm{MnSO}_{4} .4 \mathrm{H}_{2} \mathrm{O}(4 \cdot 4)$; $\mathrm{Na}_{2} \mathrm{SO}_{4}$ (345); $\mathrm{CaCl}_{2} .2 \mathrm{H}_{2} \mathrm{O}(340) ; \mathrm{Na}_{2} \mathrm{MoO}_{4} \cdot 2 \mathrm{H}_{2} \mathrm{O}$ (7.6) and ferric citrate. $5 \mathrm{H}_{2} \mathrm{O}(49)$. The medium also contained $50 \mathrm{ml} \mathrm{l}^{-1}$ of the trace element solution of Poole et al. (1979) (but omitting the cations listed above). The carbon sources were glucose $(0 \cdot 5-2 \%, w / v)$, glycerol $(1 \%$, $\mathrm{w} / \mathrm{v})$ or sodium succinate $(50 \mathrm{mM})$. The nitrogen source was ammonium sulphate $(6 \mathrm{~mm})$, tryptone $\left(0.7-1.0 \mathrm{~g} \mathrm{l}^{-1}\right)$ or 'white spot' $\mathrm{N}_{2}$ gas. All anaerobic cultures were sparged with a stream $\left(100 \mathrm{ml} \mathrm{min}^{-1}\right)$ of 'white spot' $\mathrm{N}_{2}$. When necessary the $\mathrm{O}_{2}$ transfer rate was adjusted by diluting inflowing air with $\mathrm{N}_{2}$ or by altering the stirrer speed.

The bacteria were grown in continuous culture at $30^{\circ} \mathrm{C}$ in an $800 \mathrm{ml}$ working-volume vessel at a dilution rate of $0.15 \mathrm{~h}^{-1}$. The $\mathrm{pH}$ was controlled to $6 \cdot 7+/-0.2$ by automatic addition of $2 \mathrm{M}-\mathrm{NaOH}$ or $1 \mathrm{M}-$ $\mathrm{HCl}$. The dissolved $\mathrm{O}_{2}$ concentration in the culture was measured with a lead/silver oxygen electrode (LH Engineering) calibrated at $0 \%$ and $20 \%$ air-saturation. The lowest recordable $\mathrm{O}_{2}$ concentration was about $1 \mu \mathrm{M}$. Nutrient concentrations are given in Table 1.

Bacteria were considered to be in steady-state conditions when the cell density was constant and there was no measurable limiting nutrient. The time allowed for a new steady-state to be established after a change in growth conditions was six culture volume replacements. Culture samples were tested for purity and for the $\mathrm{Nif}^{+}$phenotype by plating on minimal agar medium plus appropriate carbon source, on nutrient agar and on nitrogen-free solid medium (incubated anaerobically) as described by Cannon (1980). A given nutrient was considered to be growth-limiting when a decrease in its concentration led to a proportional decrease in cell density, when it was not detectable in the culture, and when an increase in concentration of non-limiting nutrients (nitrogen, oxygen or carbon) led to no change in cell density.

Bacteria for preparation of membranes were collected from 'overspill' culture (10 litres) (at $4{ }^{\circ} \mathrm{C}$ ) over a few days. Bacterial suspensions were concentrated (5-fold) using a Pellicon membrane system (Millipore) and then harvested, and membrane fractions prepared exactly as described by Smith $e$ t al. (1988).

The same medium as that described above was used for growth on a large scale for preparation of the $d$-type oxidase except that glucose was replaced by $0.1 \%$ glycerol plus $50 \mathrm{~mm}$-sodium succinate, the tryptone concentration was increased to $4 \mathrm{~g} \mathrm{l}^{-1}$, ammonium sulphate (20 mM) and yeast extract $\left(\mathrm{g} \mathrm{l}^{-1}\right)$ added and the phosphate concentration doubled (to $192 \mathrm{mM}$ ). Bacteria were grown in batch culture in a 20 litre fermenter at $30^{\circ} \mathrm{C}$ and harvested well-into the stationary phase (at $4 \mathrm{~d}$ ). The culture was sparged with 4 litres of air $\mathrm{min}^{-1}$ with an agitation rate of 150 r.p.m. After visible growth had occurred dissolved $\mathrm{O}_{2}$ was not detectable.

Spectrophotometric characterization of haems, cytochromes and oxidases. All spectra were recorded on a Shimadzu UV-3000 dualbeam/dual-wavelength spectrophotometer fitted with an attachment for measurements at $77 \mathrm{~K}$ when required. A spectral bandwidth of $2 \mathrm{~nm}$, a lightpath of $10 \mathrm{~mm}$ (or $2 \mathrm{~mm}$, when stated) and a scan speed of $100 \mathrm{~nm} \mathrm{~min}^{-1}$ were used. For characterization of the haems present in purified oxidase or in membrane preparations and whole bacteria the alkaline pyridine haemochrome method of Fuhrop \& Smith (1975) was used. Immediately after production of the haemochrome, the dithionite-reduced-minus-hydrogen-peroxide-oxidized difference spectrum was recorded. For determination of cytochromes in membranes, samples in $20 \mathrm{~mm}$-Tris/ $\mathrm{HCl}$ (pH 8.0) containing 1 mM-EDTA were oxidized by air (cytochrome $d$ ) or by addition of a crystal of ammonium persulphate or potassium ferricyanide. They were reduced by addition of sodium dithionite or appropriate respiratory substrate $(20 \mathrm{mM})$. The extinction coefficients for reduced-minus-oxidized spectra were those used for determination of cytochromes in $E$. coli: total cytochrome $b$, $17.5 \mathrm{~cm}^{-1} \mathrm{~mm}^{-1}$ (558-575 $\mathrm{nm}$ ) (Kita et al., 1984a); cytochrome $d$, $7 \cdot 4 \mathrm{~cm}^{-1} \mathrm{~mm}^{-1}(628-607 \mathrm{~nm})$ (Lorence et al., 1986). Determination of cytochrome $o$ was from (reduced plus $\mathrm{CO}$ )-minus-reduced spectra recorded after sparging with $\mathrm{CO}$ for $2 \mathrm{~min}$. The extinction coefficient was that used for studies of $E$. coli cytochrome $o: 145 \mathrm{~cm}^{-1} \mathrm{mM}^{-1}(416-$ $430 \mathrm{~nm})$ (Kita et al., 1984a).

Purification of the d-type cytochrome oxidase. The method was based on that of Miller \& Gennis (1983), the main difference being the replacement of chromatography on hydroxyapatite with anionexchange chromatography on Pharmacia Mono-Q. Membranes from $30 \mathrm{~g}$ wet wt of bacteria were suspended in $20 \mathrm{~mm}$-Tris/ $\mathrm{HCl}(\mathrm{pH} 8.0)$ containing $1 \mathrm{~mm}$-EDTA and $0.5 \mathrm{M}-\mathrm{KCl}$ and centrifuged at $150000 \mathrm{~g}$ for $90 \mathrm{~min}$. They were resuspended in the same buffer (lacking $\mathrm{KCl}$ ) and sodium deoxycholate added to give a final concentration of $0.2 \%$ and final protein concentration of $5 \mathrm{mg} \mathrm{m}^{-1}$. The suspension was stirred for $15 \mathrm{~min}$ on ice, the membranes sedimented (as above), and suspended in $75 \mathrm{~mm}$-potassium phosphate ( $\mathrm{pH} \mathrm{6.3),} \mathrm{containing}$ $150 \mathrm{~mm}-\mathrm{KCl}$ and $1 \mathrm{~mm}$-EDTA (buffer A). The oxidase was solubilized from the membranes by addition of $120 \mathrm{~mm}$-Zwittergent 3-12 (Calbiochem) to give a final detergent concentration of $60 \mathrm{~mm}$ and a membrane protein concentration of $12 \mathrm{mg} \mathrm{ml}^{-1}$. The mixture was stirred on ice for $30 \mathrm{~min}$ and centrifuged at $150000 \mathrm{~g}$ for $2 \mathrm{~h}$. Chromatography of the supernatant on DEAE-Sepharose FF (Pharmacia) was done essentially as described by Miller \& Gennis (1983). Pooled active fractions were concentrated about 3-fold by ultrafiltration (Amicon YM-50 membrane) to give a solution of $1 \mathrm{mg}$ protein $\mathrm{ml}^{-1}$, which was desalted on a Pharmacia PD10 column equilibrated with buffer A containing $4 \mathrm{~mm}$-Zwittergent 3-12 and chromatographed on a $1 \mathrm{ml}$ Mono-Q column equilibrated in the same buffer, using a $33 \mathrm{ml}$ linear $\mathrm{NaCl}$ gradient $(150-400 \mathrm{~mm})$. Peak fractions were concentrated to $1 \mathrm{mg}$ protein $\mathrm{ml}^{-1}$ and glycerol added to a final concentration of $10 \%(\mathrm{v} / \mathrm{v})$ before storage in liquid nitrogen.

Analytical gel filtration. This was done on a Pharmacia Superose 12 column equilibrated with buffer $A$ containing $4 \mathrm{mM}-Z$ wittergent 3-12 and run at a flow rate of $0.3 \mathrm{ml} \mathrm{min}-1$.

Determination of cytochrome $d$ during purification. This was based on the oxidation of 2,3,5,6-tetramethyl p-phenylenediamine dihydrochloride (TMPD). This was dissolved $\left(1 \mathrm{mg} \mathrm{ml}^{-1}\right)$ in $20 \mathrm{mM}$-Tris/HCl (pH 7.9) containing $0.05 \%$ Triton X-100. Samples of column fractions $(10 \mu \mathrm{l})$ were mixed with $200 \mu \mathrm{l}$ of fresh TMPD reagent in wells of microtitre plates and absorbance at $630 \mathrm{~nm}$ recorded within $2 \mathrm{~min}$ using a microtitre plate reader (Dynatech).

Protein determination and amino acid composition. Protein was measured by the bicichoninic acid method adapted for use on microtitre plates as described by Smith et al. (1988). For determination of its amino acid composition $100 \mu \mathrm{g}$ of purified oxidase was precipitated from solution with an equal volume of ice-cold acetone, washed twice in acetone, suspended in $100 \mu \mathrm{l}$ of AnalaR water (BDH) and transferred to a hydrolysis tube. $\mathrm{HCl}$ plus phenol $(0.5 \mathrm{ml}$ of $5 \mathrm{M}$ $\mathrm{HCl}$ containing $0.1 \%$ phenol) were added and the tube evacuated before hydrolysis at $110^{\circ} \mathrm{C}$ for $24 \mathrm{~h}$. Amino acids were determined on a Perkin Elmer amino acid analyser.

SDS-PAGE and assay for Nif polypeptides. SDS-PAGE was done as described by Laemmli (1970) except that samples contained a final concentration of $4 \%(w / v)$ SDS and were not heated unless specifically stated. Gels were stained with Coomassie Brilliant Blue or with silver stain (Bio-Rad). Nif polypeptides were determined by immunoblot analysis as described by Smith et al. (1988). 
Determination of oxidase activity in the oxygen electrode. $\mathrm{O}_{2}$ consumption was measured in a Rank oxygen electrode at $30^{\circ} \mathrm{C}$ in a $1 \mathrm{ml}$ reaction mixture containing $50 \mathrm{~mm}$-Tris/ $\mathrm{HCl}$ (pH 7.0 or 7.9), BSA $\left(1 \mathrm{mg} \mathrm{ml}^{-1}\right.$ ) and $0.05 \%$ Tween 20 (Sigma) or Triton X-100 (BDH). Electron donors were either $100 \mu \mathrm{M}$-ubiquinol-1 (half its $K_{\mathrm{m}}$ ) (a gift from Hoffman La Roche), $1 \mathrm{~mm}$-duroquinol (Sigma) or 1.0 mM-TMPD (Sigma). Dithiothreitol (8 $\mathrm{mM}$ ) was used to maintain the quinols in the reduced state, and $5.0 \mathrm{~mm}$-ascorbate to keep TMPD in its reduced state. Assays using duroquinol were done at pH 7.9.

Determination of the $\mathrm{O}_{2}$-affinity of the d-type cytochrome oxidase. This was measured by following the deoxygenation of leghaemoglobin. Ferric azide leghaemoglobin was a kind gift of F. J. Bergersen (CSIRO, Canberra, Australia); it was converted for use to the ferrous oxygenated form by the method of Bergersen \& Turner (1979) and oxygen affinity measured as described by Appleby \& Bergersen (1980). A glass cuvette contained $50 \mu \mathrm{M}$-oxyleghaemoglobin, $0.05 \%$ Tween 20 , $55 \mu \mathrm{M}$-ubiquinol- 1 and $8 \mathrm{~mm}$-dithiothreitol in $50 \mathrm{~mm}$-sodium phosphate buffer ( $\mathrm{pH} 7.4$ ), to give a total volume of $1.9 \mathrm{ml}$ completely filling the cuvette which was sealed with a Suba-seal so as to exclude all air. The spectrum of ferrous oxyleghaemoglobin was recorded in the dualwavelength mode between $500 \mathrm{~nm}$ and $600 \mathrm{~nm}$ (reference wavelength $587 \mathrm{~nm})$ using a buffer baseline. Purified oxidase $(5 \mu \mathrm{g})$ was added and the change in fractional saturation of oxyhaemoglobin against time was recorded at $575 \mathrm{~nm}$ (against a reference of $561 \mathrm{~nm}$ ). The free dissolved $\mathrm{O}_{2}$ concentration and total $\mathrm{O}_{2}$ in the cuvette were calculated at $6 \mathrm{~s}$ intervals during deoxygenation by the method of Bergersen \& Turner (1979) using the published binding constant of ferrous leghaemoglobin for oxygen of $43.5 \mathrm{nM}$. Steady-state kinetic data were fitted to the Michaelis-Menten equation by computer-aided iterative regression (Biodata Handling with Microcomputers by R. B. Barlow, ElsevierBiosoft).

Reconstitution of the d-type oxidase with phospholipid. Phospholipid stocks (Sigma) were stored in chloroform/methanol $(2: 1, \mathrm{v} / \mathrm{v})$ at $-20^{\circ} \mathrm{C}$. Samples were dried under $\mathrm{N}_{2}$ and solubilized by sonication until clear in $100 \mathrm{~mm}$-Tris/ $\mathrm{HCl}(\mathrm{pH} 7.9)$ containing $50 \mathrm{~mm}$-sodium cholate (recrystallized from methanol) to give a final concentration of 5-20 mg phospholipid $\mathrm{ml}^{-1}$. Total bacterial phospholipid was prepared by solvent extraction of $50 \mathrm{~g}$ wet wt $K$. pneumoniae by the method of Bligh \& Dyer (1959) as applied by Ames (1968). This was solubilized in the same way as the pure phospholipids. Equal volumes of purified oxidase $\left(1.1 \mathrm{mg} \mathrm{ml}^{-1}\right)$ and solubilized phospholipid were incubated together for $1 \mathrm{~h}$ at room-temperature and a $10 \mu \mathrm{l}$ sample of the incubation mixture diluted 100 -fold into the assay mixture used for measurement of activity in the oxygen electrode as described above (the neutral detergent was omitted from the reaction mixture).

\section{Results}

\section{Cytochromes of $K$. pneumoniae}

Spectra of pyridine haemochromes prepared from membrane fractions were characteristic of haem $b$, haem $d$ or both (see Barrett, 1956); no haem $c$ or haem $a$ was detected (data not shown). Very low concentrations of cytochrome $b$ were detected in soluble fractions, but these were not investigated further.

The spectra presented in Figs 1-3 confirm that the only cytochromes in membranes of $K$. pneumoniae were $b$ - and $d$-type cytochromes. Fig. 1 shows the spectra of membranes of bacteria grown in microaerobic condi-
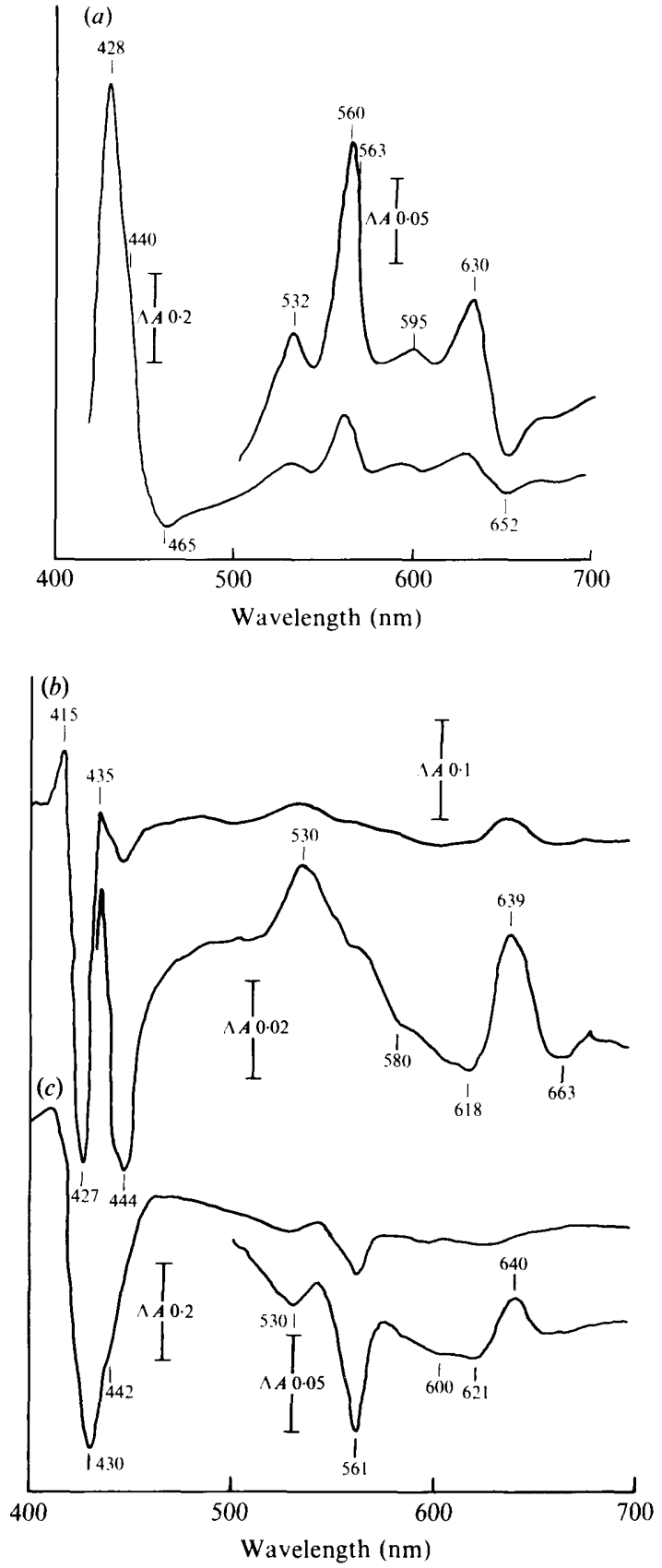

Fig. 1. Absorption spectra of membranes from bacteria grown on succinate with tryptone as nitrogen source in $\mathrm{O}_{2}$-limited, microaerobic conditions. The protein concentration was $11.3 \mathrm{mg} \mathrm{ml}^{-1}$. (a) Dithionite-reduced-minus-persulphate-oxidized difference spectrum; (b) (reduced plus $\mathrm{CO}$ )-minus-reduced difference spectrum (after sparging with $\mathrm{CO}$ for $30 \mathrm{~s})$; (c) after sparging with CO for $2 \mathrm{~min}$.

tions $\left(\mathrm{O}_{2}\right.$-limited $)$ with succinate, and tryptone as the nitrogen source. In these conditions $b$-type cytochromes (adsorbing at 557-562 $\mathrm{nm}$ ) and cytochrome $d$ (peak at $630 \mathrm{~nm}$ ) were present. In the absence of any haem $a$ the peak at $595 \mathrm{~nm}$ almost certainly corresponds to the 


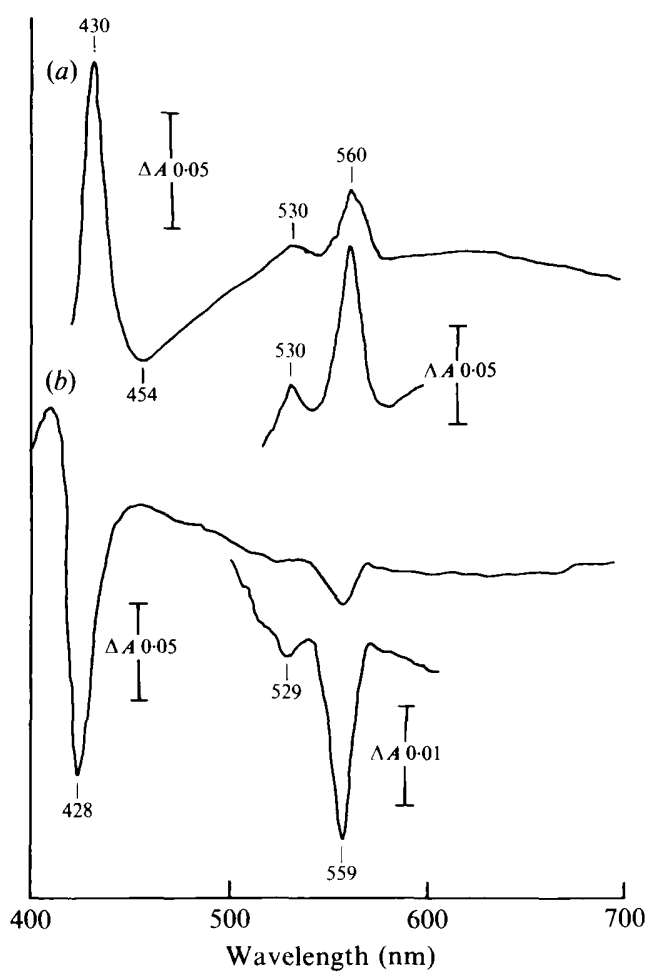

Fig. 2. Absorption spectra of membranes from bacteria grown on glycerol with tryptone as nitrogen source in nitrogen-limited conditions $\left(\mathrm{O}_{2}\right.$ concentration $\left.10-20 \mu \mathrm{M}\right)$. The protein concentration was $6.2 \mathrm{mg} \mathrm{ml}^{-1}$. (a) Dithionite-reduced-minus-persulphate-oxidized difference spectrum; (b) (reduced plus $\mathrm{CO}$ )-minus-reduced difference spectrum after sparging with $\mathrm{CO}$ for $2 \mathrm{~min}$.

cytochrome $b$-595 component of the $d$-type cytochrome oxidase of E. coli (Lorence et al., 1986; Poole, 1988); this component was also seen in the spectrum of the purified oxidase (see below). Fig. $1(b, c)$ shows that some of the $b$ type cytochrome (troughs at about $430 \mathrm{~nm}$ and $560 \mathrm{~nm}$ ) and the cytochrome $d$ (trough at about $620 \mathrm{~nm}$ ) were able to react with $\mathrm{CO}$, indicating the presence of some cytochrome $o$ (an oxidase containing haem $b$ ), and confirming the identification of the component absorbing at $630 \mathrm{~nm}$ as part of a $d$-type oxidase (see Poole, 1988 for a review of the spectra of these potential oxidases).

The spectra shown in Fig. 2 demonstrate that cytochrome $d$ was absent during growth in aerobic conditions $\left(\mathrm{O}_{2}\right.$ excess) on glycerol with tryptone as the limiting nutrient. In these growth conditions the only CO-reactive species was a $b$-type cytochrome, presumably cytochrome $o$.

Fig. 3 shows the spectra of membranes from bacteria grown on glucose with $\mathrm{N}_{2}$ as nitrogen source and $\mathrm{O}_{2}$ as the growth-limiting nutrient, which indicate that in these microaerobic conditions cytochromes $b$ and $d$ were present. The spectrum shown in Fig. 3(b) is probably due to the CO reactivity of some of the haem $b$ of the $d$-type

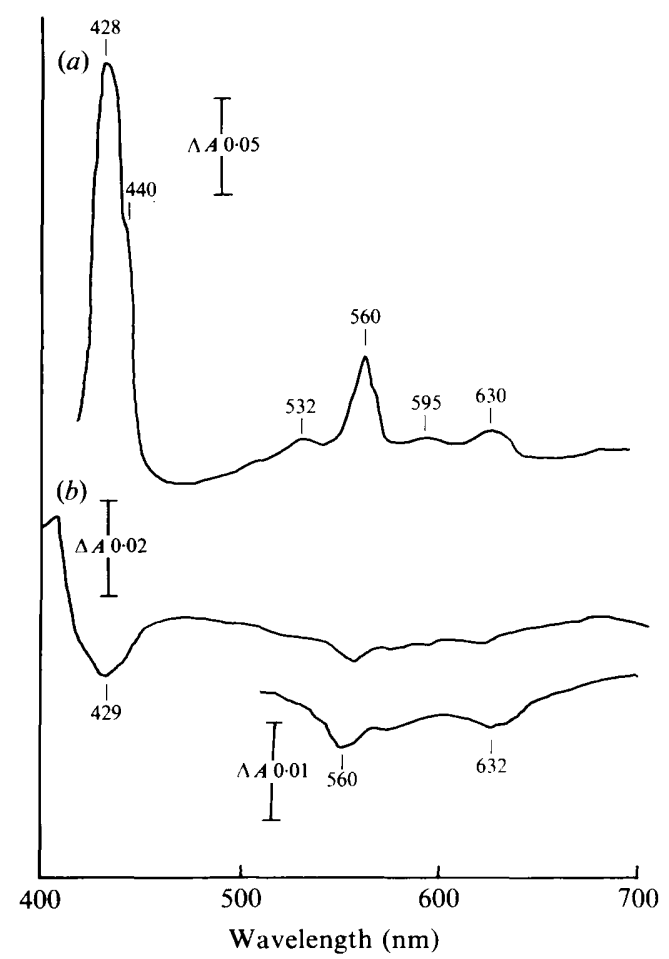

Fig. 3. Absorption spectra of membranes from nitrogen-fixing bacteria grown on glucose in $\mathrm{O}_{2}$-limited, microaerobic conditions $\left(\mathrm{O}_{2}\right.$ concentration $<1 \mu \mathrm{M})$. The protein concentration was $18 \mathrm{mg} \mathrm{ml}^{-1}$. (a) Dithionite-reduced-minus-persulphate-oxidized difference spectrum; (b) (reduced plus $\mathrm{CO}$ )-minus-reduced difference spectrum after sparging with $\mathrm{CO}$ for $2 \mathrm{~min}$.

oxidase, as shown in spectra of the pure protein (Figs 5 and 6). If the spectrum were assumed to be due to the presence of cytochrome $o$ then its content would be $6 \mathrm{nmol}(\mathrm{mg} \text { protein })^{-1}$, which is about $10 \%$ of the cytochrome $d$ content and less than $2 \%$ of the cytochrome $o$ present in any other growth conditions.

These results indicate that $K$. pneumoniae is very similar to $E$. coli in having two potential oxidases, cytochrome $o$ and cytochrome $d$, the relative amounts being determined by the growth conditions.

Table 1 summarizes the results of a broader survey of the effect of growth conditions on synthesis of the cytochromes of $K$. pneumoniae. It is evident from these results that in all anaerobic conditions the major potential oxidase was $d$-type oxidase; this was regardless of the nitrogen source $\left(\mathbf{N}_{2}\right.$, ammonia or tryptone). It is possible that the cytochrome $o$ is repressed by glucose as is the case in $E$. coli for other respiratory enzymes such as succinate dehydrogenase (Ingledew \& Poole, 1984). By contrast, cytochrome $d$ synthesis was completely repressed in the presence of excess $\mathrm{O}_{2}$, as shown previously with the oxidase of 'Klebsiella aerogenes' (Moss, 1956; Harrison, 1972) and of E. coli (Ingledew \& Poole, 1984). 
Table 1. Effect of growth conditions on synthesis of cytochromes in continuous culture

$K$. pneumoniae was grown as described in Methods with a dilution rate $(D)$ of $0 \cdot 15 \mathrm{~h}^{-1}$. The glucose concentration was $0.5 \%$ except for growth conditions 2 and 11 , when it was $2 \%$. The concentration of ammonium chloride in 3 and 7 was $6 \mathrm{~mm}$. The concentration of fumarate in 4 was $30 \mathrm{mM}$. The concentration of tryptone was $0.5 \mathrm{~g}^{-1}$ in condition $5,0 \cdot 7 \mathrm{~g}^{-1}$ in 9 and 11 , and $1 \mathrm{~g}^{-1}$ in 8 and 10 . Cytochrome concentrations in membranes were measured from difference spectra of the sort illustrated in Figs 1-3; the values presented for cytochrome $b$ are total values including the cytochrome $o$. Although the results presented here are from single steadystate cultures, each growth state was repeated at least once and the results were always within $10 \%$ of those recorded here. The lowest concentration of the cytochromes that could be determined with confidence was 10 pmol (mg membrane protein $)^{-1}$. In microaerobic conditions $\left(\mathrm{O}_{2}\right.$-limited) the $\mathrm{O}_{2}$ concentration was below the limit of detection by the oxygen electrode $(1 \mu \mathrm{M})$. In aerobic conditions the $\mathrm{O}_{2}$ concentrations were 10-200 $\mu$ M. All cultures grown with $\mathrm{N}_{2}$ as sole nitrogen source were shown to contain Nif polypeptides as detected by immunoassay. In addition to these cultures, microaerobic cultures with glycerol as carbon source and tryptone as nitrogen source also had low levels (about $5 \%$ of nitrogen-fixing cultures) of Nif polypeptides; this is indicated by $+/-$ in the Table. ND, Not detected $\left.[<10 \text { pmol cytochrome (mg membrane protein) })^{-1}\right]$.

\begin{tabular}{|c|c|c|c|c|c|c|c|}
\hline \multirow[b]{2}{*}{$\begin{array}{l}\text { Carbon } \\
\text { source }\end{array}$} & \multirow[b]{2}{*}{$\begin{array}{l}\text { Oxygen } \\
\text { status }\end{array}$} & \multirow[b]{2}{*}{$\underset{\text { polypeptides }}{\mathrm{Nif}}$} & \multirow[b]{2}{*}{$\begin{array}{l}\text { Growth } \\
\text { limitation }\end{array}$} & \multirow{2}{*}{$\begin{array}{l}\text { Nitrogen } \\
\text { source }\end{array}$} & \multicolumn{3}{|c|}{$\begin{array}{c}\text { Cytochrome concn } \\
\left.[\text { pmol (mg protein })^{-1}\right]\end{array}$} \\
\hline & & & & & Cyt. $b$ & Cyt. $o$ & Cyt. $d$ \\
\hline 1. Glucose & Anaerobic & + & Carbon & $\mathrm{N}_{2}$ & 120 & ND & 60 \\
\hline 2. Glucose & Anaerobic & + & Nitrogen & $\mathrm{N}_{2}$ & 110 & ND & 40 \\
\hline 3. Glucose & Anaerobic & - & Carbon & Ammonia & 100 & ND & 40 \\
\hline $\begin{array}{l}\text { 4. Glucose } \\
\text { + fumarate }\end{array}$ & Anaerobic & - & Carbon & $\mathrm{N}_{2}$ & 160 & ND & 70 \\
\hline 5. Glucose & Anaerobic & - & Carbon & Tryptone & 110 & ND & 50 \\
\hline 6. Glucose & Microaerobic & + & Oxygen & $\mathrm{N}_{2}$ & 130 & ND & 60 \\
\hline 7. Glucose & Microaerobic & - & Oxygen & Ammonia & 150 & ND & 60 \\
\hline 8. Glycerol & Microaerobic & $+1-$ & Oxygen & Tryptone & 560 & 180 & 170 \\
\hline 9. Succinate & Microaerobic & - & Oxygen & Tryptone & 640 & 430 & 390 \\
\hline 10. Glycerol & Aerobic & - & Nitrogen & Tryptone & 360 & 220 & ND \\
\hline 11. Succinate & Aerobic & - & Nitrogen & Tryptone & 500 & 290 & ND \\
\hline
\end{tabular}

In the present work with $K$. pneumoniae, both oxidases were only present together during respiratory growth in $\mathrm{O}_{2}$-limited conditions with glycerol or succinate, when the total cytochrome content was also at a maximum.

The only oxidase detected during nitrogen fixation was the $d$-type oxidase. This was true for all nutrient limitations tested (nitrogen, carbon or oxygen) and for growth in which the main energy source was fermentation (anaerobic) or respiration (microaerobic).

These results suggest that the nitrogen fixation occurring under microaerobic conditions may be supported by way of a respiratory chain involving cytochrome $d$. In order to investigate further this possibility, the cytochrome $d$ complex was purified and characterized with respect to its $\mathrm{O}_{2}$-affinity.

\section{Purification of the d-type oxidase}

When grown on succinate under $\mathrm{O}_{2}$-deficient conditions this oxidase constituted about $15 \%$ of the membrane protein. This was extracted and purified as described in Methods. Washing the membranes with $0.5 \mathrm{M}-\mathrm{KCl}$ removed about $20 \%$ of the total cytochrome $b$ while leaving all the cytochrome $d$ in the membranes. Extraction of these washed membranes with $0.2 \%$ deoxycholate removed little of the cytochrome $d$ but increased its specific content by $1 \cdot 5$-fold. This step was particularly useful because it led to selective release of Dlactate dehydrogenase and cytochrome $b-556$. Solubilization of the cytochrome $d$ from the resulting enriched membranes was then achieved with the zwitterionic sulphobetaine detergent Zwittergent 3-12 as described by Miller \& Gennis (1983), whose procedure forms the basis of this purification method. The results of the purification procedure are summarized in Table 2 . The yield was about $10 \%$ and the increase in purity about 10 fold on the basis of specific cytochrome $d$ content. The oxidase could not be purified further by any methods attempted and it eluted as a single symmetrical peak during FPLC gel-filtration on Pharmacia Superose 12. On the basis of this, and of SDS-PAGE, and spectral analysis $\left(A_{412} / A_{280}=0.92\right)$ it was concluded that the oxidase was at least $95 \%$ pure.

\section{$M_{r}$ of components of the purified oxidase}

SDS-PAGE showed that the oxidase consisted of two polypeptides, designated I and II. The larger subunit (I) had an apparent $M_{\mathrm{r}}$ of 52000 . As found with the enzyme from $E$. coli (Miller \& Gennis, 1983), the $M_{\mathrm{r}}$ of subunit II depended on the gel density during electrophoresis. To resolve this problem the $M_{\mathrm{r}}$ was measured for gels with a 


\section{Table 2. Purification of the d-type cytochrome oxidase}

The purification procedure is fully described in Methods. The cytochrome $b$ - 558 component was determined from the reducedminus-oxidized difference spectrum, using an extinction coefficient of $22 \mathrm{~mm}^{-1} \mathrm{~cm}^{-1}(560-580 \mathrm{~nm})($ Green et al., 1986); the cytochrome $d$ component was determined from the reduced-minusoxygenated difference spectrum, using an extinction coefficient of $7.4 \mathrm{~mm}^{-1} \mathrm{~cm}^{-1}(628-607 \mathrm{~nm})$ (Lorence et al., 1986). The values given for the membranes are prior to detergent washing. The purification factor presented is based on specific cytochrome $d$ content. When based on activities of the oxidase measured in $0.05 \%$ Triton $\mathrm{X}-100$ using ubiquinol- 1 as substrate, the purification factor was $5 \cdot 6$ overall, presumably due to loss of some activity during purification.

\begin{tabular}{|c|c|c|c|c|c|c|}
\hline \multirow{2}{*}{ Purification step } & \multirow{2}{*}{$\begin{array}{l}\text { Protein } \\
(\mathrm{mg})\end{array}$} & \multicolumn{2}{|c|}{$\begin{array}{c}\text { Cytochrome concn } \\
\left.[\text { nmol (mg protein })^{-1}\right]\end{array}$} & \multirow{2}{*}{$\begin{array}{l}A_{412} \\
A_{280}\end{array}$} & \multirow{2}{*}{$\begin{array}{l}\text { Purifi- } \\
\text { cation } \\
\text { (-fold) }\end{array}$} & \multirow{2}{*}{$\begin{array}{l}\text { Yielc } \\
(\%)\end{array}$} \\
\hline & & Cyt. $b-558$ & Cyt. $d$ & & & \\
\hline Membranes & 638 & 1.7 & $2 \cdot 0$ & -- & 1 & 100 \\
\hline $\begin{array}{l}\text { Solubilized } \\
\text { membranes }\end{array}$ & 224 & $3 \cdot 7$ & $4 \cdot 8$ & $0 \cdot 12$ & $2 \cdot 5$ & 87 \\
\hline DEAE-Sepharose & 27 & $10 \cdot 4$ & $13 \cdot 3$ & 0.54 & $6 \cdot 8$ & 29 \\
\hline Mono-Q & 6 & $15 \cdot 6$ & $19 \cdot 3$ & 0.92 & $9 \cdot 9$ & 9 \\
\hline
\end{tabular}

range of cross-linking (10-15\%, w/v, acrylamide) and the $M_{\mathrm{r}}$ determined by Ferguson analysis (Hendrich \& Smith, 1978). This gave $M_{\mathrm{r}}$ values for the subunits of 52000 and 36000 . The aggregation state of the dissociated subunits was very temperature-sensitive, $2 \mathrm{~min}$ heating $\left(\right.$ at $70^{\circ} \mathrm{C}$ ) during sample preparation for SDS-PAGE resulting in complete aggregation of subunit $I$ and its retention at the gel boundary. Boiling samples for 2 min prevented either subunit from entering the gels. Often a larger polypeptide $\left(M_{\mathrm{r}} 80000\right)$ was seen as a faint band. This was absent when the subunits were separated by preparative SDSPAGE and then run separately. When the subunits were mixed this band was once more seen, suggesting that it was due to association of the subunits during electrophoresis. During gel-filtration on Pharmacia Superose 12 in 4 mM-Zwittergent 3-12 the oxidase eluted as a single peak corrresponding to an apparent $M_{\mathrm{r}}$ of about 70000 , suggesting that it is a heterodimer with subunits of 52000 and 36000 . When this was repeated in $10 \mathrm{~mm}$-deoxycholate the oxidase was seen to be very much more highly aggregated, the apparent $M_{\mathrm{r}}$ being about 240000 .

\section{Cytochrome composition of the purified oxidase}

The absorption spectra presented in Fig. 4 show two cytochrome $b$ components (absorbing at about $560 \mathrm{~nm}$ and $595 \mathrm{~nm}$ ) and the cytochrome $d$ (absorbing at about $630 \mathrm{~nm}$ ) in the reduced form. Fig. 5 shows the characteristic absorption of the oxygenated form at

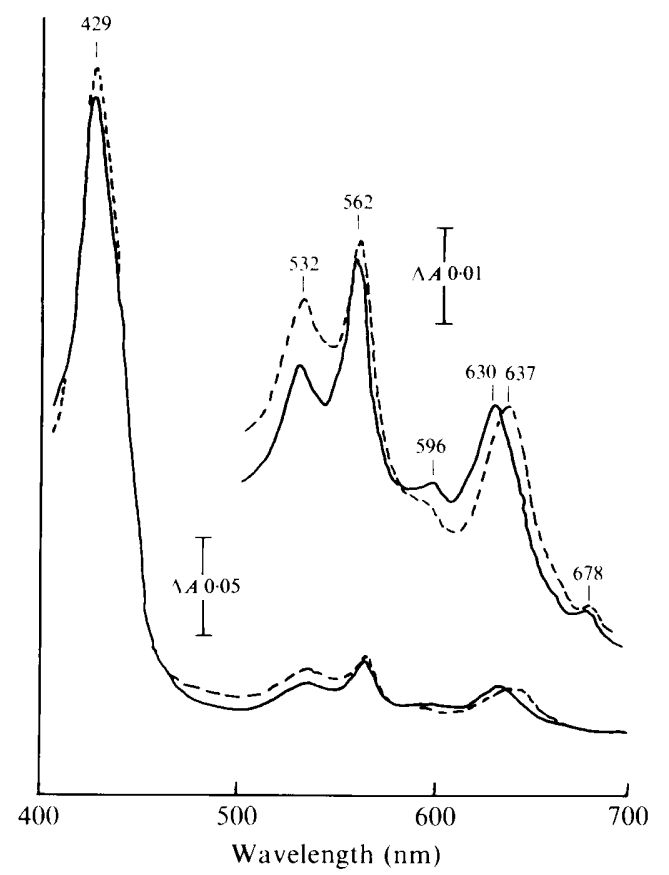

Fig. 4. Absorption spectra (room-temperature) of dithionite-reduced $d$-type cytochrome oxidase. The sample contained $65 \mu \mathrm{g}$ purified oxidase $\mathrm{ml}^{-1}$ in $75 \mathrm{~mm}$-potassium phosphate (pH 6.3) containing $150 \mathrm{~mm}-\mathrm{KCl}, 1 \mathrm{~mm}-\mathrm{EDTA}$ and $4 \mathrm{~mm}-Z$ wittergent 3-12. - , Dithionite-reduced oxidase; ----, dithionite-reduced oxidase after sparging with $\mathrm{CO}$ for $30 \mathrm{~s}$.

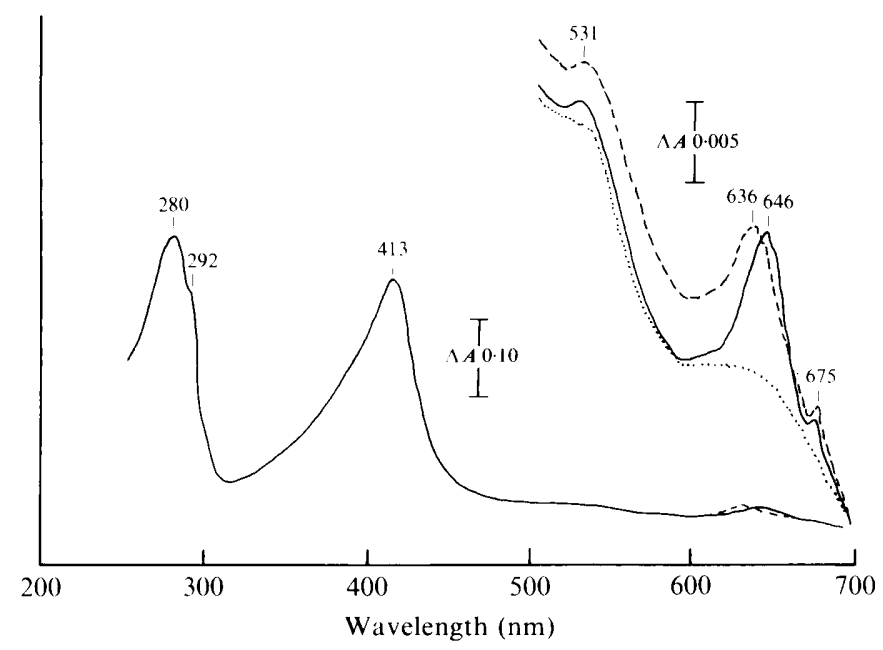

Fig. 5. Absorption spectra (room-temperature) of the air-oxidized form of the $d$-type cytochrome oxidase. Conditions are as described in Fig. 4. Spectra are as follows: —_, air-oxidized; --..--, air-oxidized after sparging with $\mathrm{CO}$ for $30 \mathrm{~s} ; \cdots \cdots$, spectrum after removal of all $\mathrm{O}_{2}$ from a sealed cuvette by addition of $5 \mathrm{~mm}$-ubiquinol- 1 and $16 \mathrm{~mm}$-dithiothreitol followed by oxidation with a trace of hydrogen peroxide $\left(6 \mu \mathrm{l} 2 \%, \mathrm{v} / \mathrm{v}, \mathrm{H}_{2} \mathrm{O}_{2}\right)$. 

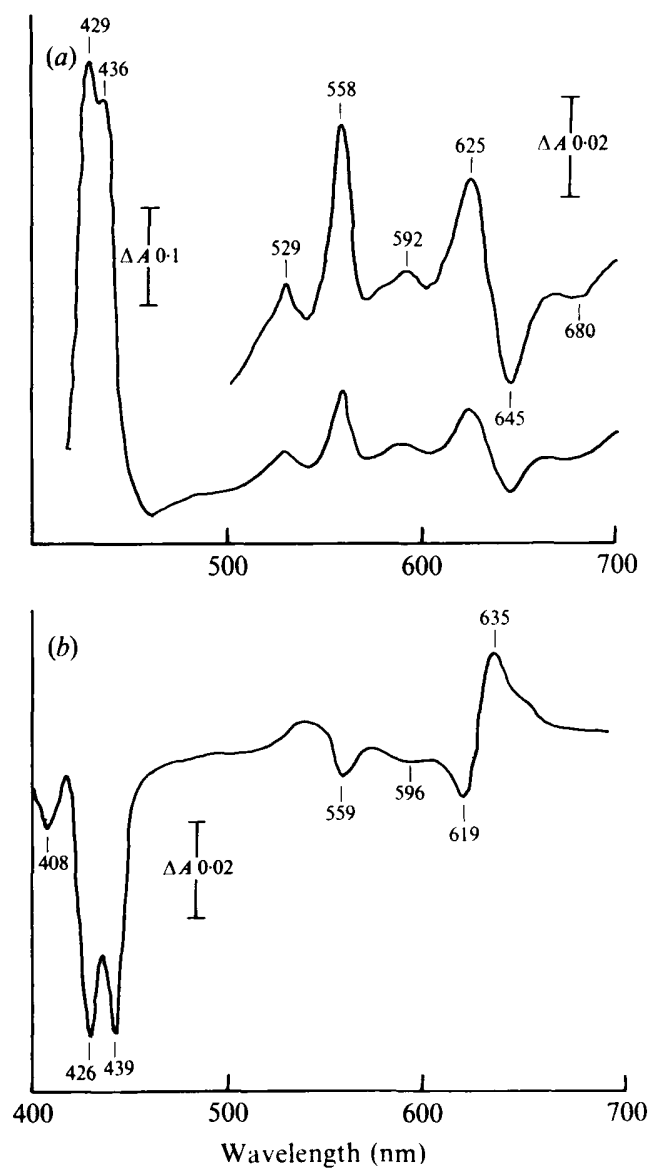

Fig. 6. Low-temperature difference spectra $(77 \mathrm{~K})$ of the $d$-type cytochrome oxidase. Conditions are as described in Fig. 4 except that the protein concentration was doubled $\left(130 \mu \mathrm{g} \mathrm{ml}^{-1}\right)$ and the lightpath was $2 \mathrm{~mm}$. (a) Dithionite-reduced-minus-air-oxidized (oxygenated) difference spectrum; $(b)$ (dithionite-reduced plus $\mathrm{CO}$ )-minus-dithionite-reduced difference spectrum (CO was sparged for $30 \mathrm{~s}$ before freezing).

about $650 \mathrm{~nm}$, which is due to formation of a stable oxygenated intermediate (Poole et al., 1983). The spectrum of the presumed oxidized form (prepared by addition of hydrogen peroxide in the absence of $\mathrm{O}_{2}$ ) is also shown. The low-temperature spectrum (Fig. 6a) shows that the peak associated with cytochrome $b-558$ was not split and so probably represents a single component. Fig. $6(b)$ shows that, over a period of $2 \mathrm{~min}$, $\mathrm{CO}$ reacted with both components, cytochrome $b$ and cytochrome $d$. Formation of pyridine haemochromes showed that no haem $a$ was present confirming that the peak at $595 \mathrm{~nm}$ (Fig. $6 a$ ) was not due to cytochrome $a_{1}$ but was due to a component containing haem $b$ as demonstrated previously for the $E$. coli enzyme (Lorence et al., 1986). The absorption spectra shown in Figs 4-6 confirm that the purified oxidase is almost identical to that of E. coli (Miller \& Gennis, 1983; Kita et al., 1984b).
The spectra also indicate that the cytochrome $b-558$, cytochrome $b-595$ and cytochrome $d$ are present in the ratio $(1.08: 1.00: 1.4$. These ratios are very similar to those determined for the $E$. coli enzyme by Lorence $e t a l$. (1986), who concluded that there are 2 mols of cytochrome $d$ per mol of oxidase complex. It should be noted, however, that more recent estimates based on EPR spectroscopy indicate that there is only $1 \mathrm{~mol}$ each of cytochrome $b-595$ and cytochrome $d$ per mol of the $E$. coli oxidase (Rothery \& Ingledew, 1989).

\section{Amino acid composition of the oxidase}

The amino acid composition was similar to that published by Miller \& Gennis (1983) for the E. coli enzyme whose values are presented in the following list (percentage of each amino acid per mol): Asx, 7.8 (8.2); Thr, 4.2 (6.2); Ser, 3.2 (4.9); Glx, 7.6 (7.2); Gly, 11·7 (9.3); Ala, 10.6 (11.5); Val, 8.4 (8.8); Met, 4.4 (3.5); Pro, 4.0 (4.1); Ile, 5.5 (7.1); Leu, 13.0 (12.8); Tyr, 3.7 (3.4); Phe, 8.0 (6.9); His, 2.3 (1.5); Lys, 2.8 (4.1); Arg, $1.6(1.4)$.

Antisera raised to the complete oxidase of $K$. pneumoniae reacted with a polypeptide on Western blots of SDS extracts of E. coli membranes that comigrated with subunit I of the $K$. pneumoniae. Subunit II failed to transfer efficiently during blotting as noted previously by Kranz \& Gennis (1985).

\section{Substrate specificity and kinetic studies of the oxidase}

Table 3 presents the steady-state kinetic parameters of the purified oxidase which demonstrate that the preparation is an active oxidase. The $\mathrm{pH}$ optimum with ubiquinol-1 as substrate was $7 \cdot 9(+/-0 \cdot 1)$. The specific activity was about $30 \%$ of that of the oxidase isolated from $E$. coli (Miller \& Gennis, 1983). The turnover number (kkat) of the oxidase (in terms of cytochrome $d$

Table 3. Steady-state kinetic parameters of the d-type cytochrome oxidase

All reaction mixtures contained $0.05 \%$ Triton X-100 and all rates were corrected for any auto-oxidation of substrates. ND, Not determined.

\begin{tabular}{lccc}
\hline \hline Substrate & $\mathrm{pH}$ & $\begin{array}{c}K_{\mathrm{m}} \\
(\mathrm{mM})\end{array}$ & $\begin{array}{c}V\left[\mu \mathrm{mol} \mathrm{O}_{2} \mathrm{~min}^{-1}\right. \\
(\mathrm{mg} \text { protein) }\end{array}$ \\
\hline Ubiquinol-1 & 7.0 & 0.22 & 50 \\
Ubiquinol-1 & 7.9 & 0.21 & 117 \\
Duroquinol & 7.0 & 0.19 & 10 \\
Duroquinol & 7.9 & $\mathrm{ND}$ & 18 \\
TMPD & 7.0 & 2.8 & 32 \\
\hline \hline
\end{tabular}


content) was $400 \mathrm{~s}^{-1}$ at $\mathrm{pH} 7.9$ with ubiquinol-1 as substrate and with $0.05 \%$ Triton $\mathrm{X}-100$ in the reaction mixture. This compares with an estimated turnover number in vivo (for a range of growth states) of 300$700 \mathrm{~s}^{-1}$. The natural substrate for the oxidase is likely to be ubiquinol-8, the predominant form of quinone in enteric bacteria. When using ubiquinol- 1 as substrate the $K_{\mathrm{i}}$ for KCN was $0.33 \mathrm{~mm}$; this compares with the value of $2 \mathrm{mM}-\mathrm{KCN}$ required for $50 \%$ inhibition of the enzyme from E. coli (Anraku \& Gennis, 1987).

\section{Requirement for activity of the oxidase for detergent or neutral lipid}

The oxidase was similar to mitochondrial cytochrome $a a_{3}$ in that it was largely inactive after isolation and purification when assayed in the absence of phospholipid or neutral detergents (Table 4). There was no activity when the charged detergent (cholate) or the zwitterionic detergent (Zwittergent 3-12) that were used in the solublization and purification of the enzyme replaced the neutral detergents Tween or Triton as shown in preliminary studies of the $E$. coli oxidase (Lorence et al., 1986). Exchanging Zwittergent 3-12 with cholate by gel-filtration prior to assay had no effect on the measured rates. The optimum concentration of Tween 20 in the assay mixture was about $0.05 \%$. Above
$0 \cdot 2 \%$ this detergent was inhibitory. The results in Table 4 also show that the neutral detergent was not required when the oxidase was first reconstituted with phospholipid prior to assay. The highest activity was obtained with phospholipids extracted from $K$. pneumoniae, but rates were not much lower when phosphatidylglycerol or phosphatidylethanolamine were used; these are the main phospholipids of membranes of E. coli, and probably also of $K$. pneumoniae (Ames, 1968).

\section{Affinity of pure d-type oxidase for $\mathrm{O}_{2}$}

Estimates of the $\mathrm{O}_{2}$-affinity of the cytochrome $d$ of other bacteria have been published but these have been based on measurements with oxygen electrodes which are not suitable for accurate determinations at low $\mathrm{O}_{2}$ concentrations (Hill, 1988). The purified $d$-type oxidase from $K$. pneumoniae was able to catalyse the removal of $\mathrm{O}_{2}$ from a solution containing soyabean oxyleghaemoglobin $\left(K_{\mathrm{s}}\right.$ $43.5 \mathrm{nM})$ resulting in its complete deoxygenation. The rate of the later phase of deoxygenation was used to calculate the steady-state $\mathrm{O}_{2}$-consumption kinetics at concentrations of free $\mathrm{O}_{2}$ below $200 \mathrm{nM}$. The results (not shown) demonstrated that the oxidase has a single highaffinity site for binding $\mathrm{O}_{2}$ with an apparent $K_{\mathrm{m}}$ value of $20 \mathrm{nM}$. This value is much lower than that published for any other purified bacterial oxidase and, in particular, it

\section{Table 4. Dependence of d-type cytochrome oxidase activity on detergents or phospholipids}

Activity was measured in the standard oxygen electrode assay system with duroquinol ( $1 \mathrm{~mm}$ ) as substrate using oxidase isolated in Zwittergent 3-12. The values in parentheses are for oxidase which was first transferred to $5 \mathrm{~mm}$-cholate by passage down a PD10 gel-filtration column. To measure the effect of phospholipid on activity of the oxidase equal volumes of purified oxidase were mixed with phospholipid (previously solubilized in Tris/ $\mathrm{HCl}$ buffer $(\mathrm{pH} 7.9)$ containing $50 \mathrm{mM}$-cholate as described in Methods. The final concentrations of phospholipid in the 'reconstitution' mixtures were as follows $\left(\mathrm{mg} \mathrm{ml}^{-1}\right)$ : phosphatidylcholine (10); phosphatidylglycerol (9.5); phosphatidylethanolamine (5.0); and total phospholipid from K. pneumoniae (5.0). Activity of the oxidase was then determined by using $0.01 \mathrm{ml}$ of this mixture in a $1 \mathrm{ml}$ reaction mixture in an oxygen electrode. All the 'reconstitution' assays recorded below therefore contain $0.5 \mathrm{~mm}$-cholate. For the control recorded in the Table, cholate was omitted from the 'reconstitution' mixture. The recorded values are means of three assays, all of which gave values within $5 \%$ of those recorded. Although no systematic examination of the effect of phospholipid concentration was undertaken, doubling of the phospholipid concentrations did not increase the activities above the values recorded below. It should be noted that the incubation period in Tris buffer, which was part of the 'reconstitution' process, led to a decrease to $48 \%$ of the specific activity of the oxidase (assayed in the presence of Tween 20); the activities recorded after 'reconstitution' should therefore be compared with a control value of $5 \cdot 7 \mu \mathrm{mol} \mathrm{min}^{-1}(\mathrm{mg} \text { protein })^{-1}$.

\begin{tabular}{|c|c|c|c|}
\hline \multicolumn{2}{|c|}{ Activity in standard assay } & \multicolumn{2}{|c|}{ Activity after 'reconstitution' } \\
\hline Detergent & $\begin{array}{c}\text { Specific activity } \\
{\left[\mu \mathrm{mol} \mathrm{O}_{2} \mathrm{~min}^{-1}(\mathrm{mg} \text { protein })^{-1}\right]}\end{array}$ & Phospholipid & $\begin{array}{c}\text { Specific activity } \\
{\left[\mu \mathrm{mol} \mathrm{O}_{2} \min ^{-1}(\mathrm{mg} \text { protein })^{-1}\right]}\end{array}$ \\
\hline None & $0.02(0.02)$ & None & 0.70 \\
\hline Triton X-100 (0.05\%) & $4.93(5 \cdot 22)$ & Phosphatidylcholine & 1.04 \\
\hline Tween $20(0.05 \%)$ & $11.94(13.00)$ & Phosphatidylglycerol & $7 \cdot 46$ \\
\hline Cholate $(0.05 \%)$ & $0.07(0 \cdot 14)$ & Phosphatidylethanolamine & $7 \cdot 02$ \\
\hline Zwittergent $(0.5 \%)$ & $0.02(0.02)$ & Total phospholipid from & $8 \cdot 50$ \\
\hline $\begin{array}{l}\text { Cholate }(0.05 \%) \text { plus } \\
\text { Tween } 20(0.05 \%)\end{array}$ & $7 \cdot 31$ & K. pneumoniae & \\
\hline
\end{tabular}


is much lower than that measured for the purified oxidase of $E$. coli ( $380 \mathrm{nM}$ ) (Kita et al., 1984b). However, the value for the $E$. coli enzyme was obtained from measurements with an oxygen electrode and hence is likely to be subject to error for measurements at low $\mathrm{O}_{2}$ concentrations. The value assigned to the oxidase in whole cells of $E$. coli (Rice \& Hempfling, 1978) was closer to the value measured for the pure oxidase from $K$. pneumoniae in the present work.

It has been previously shown that $50 \%$ inhibition of activity and synthesis of nitrogenase occurred at about $100 \mathrm{nM}-\mathrm{O}_{2}$ which was close to the $K_{\mathrm{s}}$ of the dominant terminal oxidase; this was estimated from $\mathrm{O}_{2}$-consumption measurements with whole bacteria using the same system for $\mathrm{O}_{2}$ determination as used in the present work for measurement of the $K_{\mathrm{m}}$ value for the purified oxidase (Bergersen \& Turner, 1979; Bergersen et al., 1982; Hill et al., 1984). The estimated value using whole bacteria was about $80 \mathrm{~nm}$. The apparent discrepancy between this value and that for the oxidase purified in the present work (20 mM) must presumably be due to $\mathrm{O}_{2}$-gradients between the growth medium and the site of binding of $\mathrm{O}_{2}$ to the oxidase.

\section{Discussion}

The results described above confirm that $K$. pneumoniae contains a $d$-type oxidase very similar to that previously described in E. coli (Miller \& Gennis, 1983; Lorence et al., 1986; Miller et al., 1988; Kita et al., 1984b; Finlayson $\&$ Ingledew, 1985). The exceptionally high affinity for $\mathrm{O}_{2}$ may be a unique property of the $K$. pneumoniae $d$-type oxidase.

In $E$. coli no specific role for the oxidases containing cytochrome $d$ or cytochrome $o$ has been proposed, mutants lacking either enzyme being able to grow normally under laboratory conditions (Au et al., 1985; Green \& Gennis, 1983). Georgiou et al. (1988) have shown that the regulation of synthesis of cytochrome $d$ in $E$. coli is at the level of transcription, the $c y d$ operon being transcriptionally inactive at high $\mathrm{O}_{2}$ concentrations. They concluded that there was no obvious need for the oxidase, except perhaps as an $\mathrm{O}_{2}$-scavenger, for which there has been no demonstrated need in $E$. coli.

The main feature that distinguishes $K$. pneumoniae from $E$. coli is that $K$. pneumoniae is able to fix nitrogen. In this organism the $d$-type oxidase was always produced in nitrogen-fixing conditions, when it was the sole oxidase. Its most important property in this context is its extremely high affinity for $\mathrm{O}_{2}$, the highest affinity for any oxidase previously described $\left(K_{\mathrm{m}} 20 \mathrm{nM}\right)$. It is proposed that this ensures that it is able to lower the free $\mathrm{O}_{2}$ concentration in solution so that nitrogenase synthe- sis may be derepressed and so that it may be protected from the inhibitory effects of $\mathrm{O}_{2}$ (respiratory protection) as previously proposed for Azotobacter (Yates, 1988). The affinity of the alternative oxidase, cytochrome $o\left(K_{\mathrm{m}}\right.$ $200 \mathrm{nM}$ ), measured in whole cells of $E$. coli, is about $10 \%$ of that of cytochrome $d$ and hence usually unable to maintain the low $\mathrm{O}_{2}$ concentration essential for derepression of nitrogenase (less than about $100 \mathrm{nM}$ ). It is also proposed that the $d$-type oxidase is able to function as the terminal oxidase in an energy-generating electron transport chain in order to support an enhanced efficiency of nitrogen fixation at low $\mathrm{O}_{2}$ concentrations. The presence of this oxidase after anaerobic growth on glucose presumably explains why, after glucose depletion, nitrogen fixation only occurs in the presence of added $\mathrm{O}_{2}$ (Hill, 1976). We presume that the glucose fermentation products are providing electrons for this electron transport to $\mathrm{O}_{2}$ by way of the $d$-type oxidase described in this work. To test these proposals it will be necessary to characterize cyd mutants with respect to microaerobic nitrogen fixation (it should not occur) and to identify those fermentation substrates which are able to support electron transport by way of cytochrome $d$.

It is clear that this proposed role for the $d$-type oxidase is not directly relevant to its function in $E$. coli as that organism does not fix nitrogen. It is possible that this high-affinity $d$-type oxidase may have developed (evolutionarily) in nitrogen-fixing Klebsiella and that its presence in $E$. coli might merely reflect its retention rather than a specific function in this organism. Alternatively, the present work directs attention to the possibility that in $E$. coli there may be some, as yet unidentified, oxygen-sensitive enzymes whose activities provide some benefit to the organism in microaerobic growth conditions.

We thank Dr F. J. Bergersen for the gift of soyabean leghaemoglobin and for advice on its use, and Professors B. E. Smith and R. B. Gennis for constructive criticism of the manuscript. We also thank Dr D. Bloxham of the Vitamins and Fine Chemicals Division of Hoffman La Roche for a generous gift of ubiquinone-1. A.S. thanks the SERC for a CASE studentship with the AFRC IPSR Nitrogen Fixation Laboratory.

\section{References}

AMEs, G. F. (1968). Lipids of Salmonella typhimurium and Escherichia coli: structure and metabolism. Journal of Bacteriology 95, 833-843.

ANRAKU, Y. \& GENNIS, R. B. (1987). The aerobic respiratory chain of Escherichia coli. Trends in Biochemical Sciences 139, 262-266.

Appleby, C. A. \& Bergersen, F. J. (1980). Preparation and the experimental use of leghaemoglobin. In Methods for Evaluating Biological Nitrogen Fixation, pp. 315-335. Edited by F. J. Bergersen. Chichester: J. Wiley. 
Au, D. C. T., LoRenCe, R. M. \& Gennis, R. B. (1985). Isolation and characterization of an Escherichia coli mutant lacking the cytochrome $o$ terminal oxidase. Journal of Bacteriology 161, 123-127.

BARRETT, J. (1956). The prosthetic group of cytochrome $a_{2}$. Biochemical Journal 64, 626-639.

Bergersen, F. J. \& TURner, G. L. (1979). Systems utilising oxygenated leghaemoglobin and myoglobin as sources of free dissolved oxygen at low concentrations for experiments with bacteria. Analytical Biochemistry 96, 165-174.

Bergersen, F. J., KenNedy, C. \& Hill, S. (1982). The influence of low oxygen concentrations on derepression of nitrogenase in Klebsiella pneumoniae. Journal of General Microbiology 128, 909-915.

BLIGH, E. G. \& DYER, W. J. (1959). A rapid method for total lipid extraction and purification. Canadian Journal of Biochemistry and Physiology 37, 911-917.

CanNon, F. C. (1980). Genetic studies with diazotrophs. In Methods for Evaluating Nitrogen Fixation, pp. 367-413. Edited by F. J. Bergersen. Chichester: J. Wiley.

Finlayson, S. D. \& Ingledew, W. J. (1985). Cytochrome $b d$ of Escherichia coli: its isolation and study by EPR. Biochemical Society Transactions 13, 632-633.

Furhop, J. H. \& SMITH, K. M. (1975). Laboratory methods. In Porphyrins and Metalloporphyrins, pp. 757-869. Edited by K. M. Smith. Amsterdam: Elsevier.

Georgiou, C. D., DueweKe, T. J. \& Gennis, R. B. (1988). Regulation of expression of the cytochrome $d$ terminal oxidase in Escherichia coli is transcriptional. Journal of Bacteriology 170, 961-966.

GREEN, G. N. \& GENNIS, R. B. (1983). Isolation and characterization of an Escherichia coli mutant lacking cytochrome $d$ terminal oxidase. Journal of Bacteriology 154, 1269-1275.

Harrison, D. E. F. (1972). Physiological effects of dissolved oxygen potential and redox potential on growing populations of microorganisms. Journal of Applied Chemistry and Biotechnology 22, $417-446$.

Hendrich, J. L. \& SMith, A. J. (1978). Size and charge isomer separation and estimation of molecular weights of proteins by disc gel electrophoresis. Archives of Biochemistry and Biophysics 1126, 155-164.

HILL, S. (1976). Influence of atmospheric oxygen concentration on acetylene reduction and efficiency of nitrogen fixation in intact Klebsiella pneumoniae. Journal of General Microbiology 93, 335-345.

HILL, S. (1988). How is nitrogenase regulated by oxygen? FEMS Microbiology Reviews 54, 111-130.

Hill, S., TURner, G. L. \& Bergersen, F. J. (1984). Synthesis and activity of nitrogenase in Klebsiella pneumoniae exposed to low concentrations of oxygen. Journal of General Microbiology 130 , $1061-1067$

INGLedew, W. J. \& PoOLE, R. K. (1984). The respiratory chains of Escherichia coli. Microbiological Revues 48, 222-271.

KITA, K., Konishi, K. \& ANRAKU, Y. (1984a). Terminal oxidases of the Escherichia coli aerobic respiratory chain: purification and properties of cytochrome $b_{562} \mathrm{o}$ complex from cells in early exponential phase of aerobic growth. Journal of Biological Chemistry 259 , 3368-3374.
Kita, K., Konishi, K. \& ANRAKU, Y. (1984b). Terminal oxidases of Escherichia coli respiratory chain. Purification and properties of the cytochrome $b$-558d complex from cells grown with limited oxygen, and evidence of a branched electron carrying system. Journal of Biological Chemistry 259, 3375-3381.

KRANZ, G. R. \& GENNIS, R. B. (1985). Immunological investigation of the distribution of cytochromes related to the two terminal oxidases of Escherichia coli in other Gram-negative bacteria. Journal of Bacteriology 161, 709-713.

KRANZ, R. G., Barassi, C. J. \& GenNis, R. B. (1984). Immunological analysis of the heme proteins present in aerobically-grown Escherichia coli. Journal of Bacteriology 158, 1191-1194.

LAEMMLI, U. K. (1970). Cleavage of structural proteins during the assembly of the head of bacteriophage T4. Nature, London 227, 680-685.

LoRence, R. M., Koland, J. G. \& Gennis, R. B. (1986). Coulometric and spectroscopic analysis of the purified cytochrome $d$ oxidase complex of Escherichia coli: evidence for the identification of 'cytochrome $a_{1}$ ' as cytochrome $b_{595}$. Biochemistry 25, 2314-2321.

Miller, M. J. \& GenNIS, R. B. (1983). Purification and characterisation of the cytochrome $d$ terminal oxidase complex from Escherichia coli. Journal of Biological Chemistry 248, 9159-9165.

Miller, M. J., Hermodson, M. \& Gennis, R. B. (1988). The active form of the cytochrome $d$ terminal oxidase complex of Escherichia coli is a heterodimer containing one copy of each of the two subunits. Journal of Biological Chemistry 263, 5235-5240.

Moss, F. (1956). Adaptation of the cytochromes of Aerobacter aerogenes in response to environmental oxygen tension. Australian Journal of Experimental Biology 34, 395-406.

PoOLE, R. K. (1988). Bacterial cytochrome oxidases. In Bacterial Energy Transduction, pp. 231-291. Edited by C. Anthony. London: Academic Press.

Poole, R. K., Waring, A. J. \& Chance, B. (1979). The reaction of cytochrome $o$ in Escherichia coli with oxygen. Biochemical Journal 184, 379-389.

Poole, R. K., Kumar, C., Salmon, I. \& Chance, B. (1983). The $650 \mathrm{~nm}$ chromophore in Escherichia coli is an oxygenated compound, not the oxidized form of cytochrome $d$ oxidase; an hypothesis. Journal of General Microbiology 129, 1335-1344.

Rice, C. W. \& Hempfling, W. P. (1978). Oxygen-limited continuous culture and respiratory enzymes in Escherichia coli. Journal of Bacteriology 134, 115-124.

ROTHERY, R. A. \& INGLedew, W. J. (1989). The cytochromes of anaerobically-grown Escherichia coli: an electron paramagnetic resonance study of the in situ cytochrome $b d$ complex. Biochemical Journal 261, 437-443.

Smith, A., Hill, S. \& ANTHonY, C. (1988). A haemoprotein is not involved in the control by oxygen of enteric nitrogenase synthesis. Journal of General Microbiology 134, 1499-1507.

YATES, M. G. (1988). The role of oxygen and hydrogen in nitrogen fixation. Symposia of the Society for General Microbiology 42 , 383-416. 